\title{
Jurist-Diction
}

Volume 3 No. 6, November 2020

\section{Pemenuhan Tunjangan Hari Raya Dalam Tahun Anggaran 2018 Kepada ASN (Aparatur Sipil Negara)}

\author{
Daniel Dwi Setyoko \\ daniel.dwi.setyoko-2015@fh.unair.ac.id \\ Universitas Airlangga
}

How to cite:

Daniel Dwi Setyoko,

'Pemenuhan Tunjangan Hari Raya Dalam Tahun Anggaran 2018 Kepada ASN (Aparatur Sipil Negara)' (2020) Vol. 3 No. 6 Jurist-Diction.

Histori artikel:

Submit 1 September 2020;

Diterima 22 September 2020;

Diterbitkan 1 November 2020.

DOI:

10.20473/jd.v3i6.22959

\begin{abstract}
Abstrak
Tunjangan merupakan salah satu hak yang didapat oleh ASN berdasarkan Undang-undang Nomor 5 Tahun 2014 tentang ASN. Tunjangan tersebut berfungsi sebagai balas jasa atas kinerja ASN disamping gaji pokok demi terjaminnya kesejahteraan ASN. Sejak tahun 2016 Presiden Joko Widodo memutuskan untuk tidak menaikan gaji ASN. Sebagai ganti atas tidak naiknya gaji ASN, Pemerintah Pusat memberikan Tunjangan Hari Raya menjelang hari raya Idul Fitri tahun 2016. Pemberian Tunjafngan Hari Raya terus dilakukan hingga pada tahun 2018 Tunjangan tersebut mengalami penyesuaian. Melalui Peraturan Pemerintah Nomor 19 Tahun 2018, pemerintah pusat menaikan Tunjangan Hari Raya yang sebelumnya sebesar gaji pokok menjadi sebesar penghasilan pada bulan Mei 2018. Pemerintah Kota Surabaya berdalih tidak mempunyai anggaran untuk belanja pegawai pada APBD Kota Surabaya tahun anggaran 2018. Pemenuhan Tunjangan Hari Raya merupakan hal yang penting sebab menyangkut hak-hak ASN yang telah bekerja pada pemerintah. Tunjangan tersebut juga menunjang kebutuhan ekonomi para ASN menjelang Hari Raya Idul Fitri tahun 2018. Pemenuhan tersebut berdampak pada anggaran pemerintah. Evaluasi dan Perubahan pada APBN dan APBD wajib dilakukan pemerintah untuk menyesuaikan kebutuhan biaya yang ada. Kata Kunci: Tunjangan Hari Raya; Aparatur Sipil Negara; Pengelolaan Keuangan Negara; Perubahan APBD.
\end{abstract}

\section{Pendahuluan}

Aparatur sipil negara atau yang seterusnya disingkat ASN merupakan profesi bagi pegawai negeri sipil dan pegawai pemerintahan dengan perjanjian kerja yang bekerja pada instansi pemerintahan. Hal tersebut didasarkan pada UndangUndang nomor 5 tahun 2014 tentang Aparatur Sipil Negara pasal 1 angka 1. Untuk selanjutnya Undang-Undang nomor 5 tahun 2014 tentang Aparatur Sipil Negara disebut sebagai UU ASN. Adapun termasuk kedalam pegawai ASN sesuai dengan UUASN pasal 1 angka 2, antara lain: pegawai negeri sipil dan pegawai pemerintahan dengan perjanjian kerja yang diangkat oleh pejabat pembina kepegawaian dan 
diserahi tugas dalam suatu jabatan pemerintahan atau diserahi tugas negara lainnya dan digaji berdasarkan peraturan perundang-undangan.

Dalam kaitannya sebagai aparatur negara, para pegawai ASN langsung menjadi bagian dari Korps Profesi ASN. Berdasarkan pasal 126 ayat (1) UU ASN, bahwa seluruh pegawai ASN menjadi anggota Korps Profesi ASN.Korps Profesi ASN bertujuan untuk menjaga kode etik dan standar pelayanan profesi ASN dan mewujudkan jiwa korps ASN sebagai pemersatu bangsa.Dengan tergabungnya seluruh anggota ASN dalam naungan Korps Profesi ASN, dapat terjaminnya perlindungan hukum ASN dan bantuan advokasi saat mengalamai masalah hukum dalam menjalankan tugasnya.Korps Profesi ASN juga turut serta dalam pengembangan dan pembinaan ASN, sehingga ASN terjamin pula kesejahteraannya. Tergabungnya ASN dalam Korps Profesi ASN, memunculkan konsekuensi bahwa sebagai pejabat umum, bahwa ASN sepenuhnya dalam menjalankan tugasnya didasarkan pada pelayanan pada masyarakat.

Pelayanan publik yang dilakukan oleh ASN tidak hanya didasarkan pada ketentuan UU ASN saja. Sebagai konsekuensi dibaginya ASN menjadi 2 kategori yaitu ASN pusat dan daerah, maka diatur pula hak dan kewajiban bagi ASN terutama ASN daerah pada Undang-Undang nomor 23 tahun 2014 tentang Pemerintah Daerah untuk seterusnya disebut UU Pemda. UU pemda merupakan panduan pokok bagi pemerintah daerah dalam menjalankan roda pemerintahan daerah. Segala kewenangan pemerintah daerah provinsi dan pemerintah kabupaten/ kota diatur secara rinci dalam peraturan tersebut. Sehingga pemerintah daerah dalam menjalankan pemerintahannya berdasarkan prinsip desentralisasi dan otonomi.

Yang dimaksud desentralisasi adalah penyerahan urusan pemerintahan oleh pemeritah pusat kepada daerah otonom berdasarkan asas otonomi, hal tersebut didasarkan pada UU pemda pasal 1 angka 8. Peran pemerintah pusat dalam menjalankan desentralisasi adalah dengan mengadakan Dana Alokasi Khusus (DAK) dialokasikan dari Anggaran Pendapatan dan Belanja Negara (APBN) kepada daerah tertentu dalam rangka pendanaan pelaksanaan desentralisasi untuk mendanai kegiatan khusus yang ditentukan pemerintah atas dasar prioritas 
nasional. ${ }^{1}$ Sehingga berimplikasi bahwa, daerah yang telah dilimpahi wewenang dari pemerintah pusat dapat melakukan kegiatan rumah tangga daerah secara mandiri dan mampu merencanakan pembangunannya sendiri dan mengatur stabilitas politik di daerah masing-masing.Disamping itu pula mampu mengangkat perangkat dan pelaksanaanya dengan pembiayaan sendiri yang diperoleh dari kegiatan rumah tangga daerah tersebut.

Disamping desentralisasi, pada UU Pemda dikenal pula istilah Otonomi daerah.Otonomi diambil dari kata outos yang artinya sendiri dan nomos yang artinya hukum. ${ }^{2}$ Sehingga otonomi berarti kewenangan untuk mengatur dan membuat hukumnya sendiri. Hal tersebut berimplikasi bahwa pemerintahan yang menjalankan otonomi dapat membentuk produk hukum, menjalankan produk hukum, mengadili, dan menindak sendiri. ${ }^{3}$ Di Indonesia prinsip otonomi dituangkan kedalam UU Pemda dalam otonomi daerah. Otonomi daerah adalah hak, wewenang, dan kewajiban daerah otonom untuk mengatur dan mengurus sendiri Urusan Pemerintah dan kepentingan masyarakat setempat dalam sistem Negara Kesatuan Republik Indonesia.

Dengan adanya desentralisasi dan prinsip otonomi sebagai dasar pelaksanaan pemerintahan daerah, pemerintah daerah perlu membentuk perangkat daerah.Yang dimaksud perangkat daerah berdasarkan UU pemda adalah unsur pembantu kepala daerah dan DPRD dalam penyelenggaraan Urusan Pemerintahan yang menjadi kewenangan Daerah.Pembentukan perangkat daerah didasarkan pada kemampuan dan kondisi daerah tersebut agar sesuai dengan kebutuhan dan pelaksanaan pemerintahan daerah.Dalam pengisian jabatan pada perangkat daerah, haruslah pegawai ASN.Pengisian dengan pegawai ASN didasarkan pada ketentuan pasal 208 ayat (2) UU pemda. Sebagaimana yang dijelaskan sebelumnya, bahwa ASN

\footnotetext{
${ }^{1}$.Siswanto Sunarno, Hukum Pemerintahan Daerah Di Indonesia (Sinar Grafika Offset 2008).[79].

2 Yusdianto, 'Hubungan Kewenangan Pusat dan Daerah Menurut Undang-Undang Nomor 23 Tahun 2014 tentang Pemerintahan Daerah’ (2015) Volume 2 Nomor 3 PADJADJARAN Jurnal Ilmu Hukum.[495].

${ }_{3}$ Mahfud MD, Politik Hukum di Indonesia (Penerbit LP3ES 1998).[93].
} 
dibagi menjadi 2 yaitu ASN pusat dan ASN daerah, sehingga guna mengisi jabatan perangkat daerah provinsi dan kabupaten atau kota adalah termasuk ASN daerah.

ASN daerah memiliki kewajiban dan hak yang diatur secara umum dalam UU ASN.Adapun kewajiban tersebut mengikat seluruh ASN baik pusat dan daerah. Kewajiban ASN diatur pada pasal 23 UU ASN antara lain : Setia dan taat kepada Pancasila, UUD Tahun 1945, NKRI, dan pemerintah yang sah; Menjaga persatuan dan kesatuan bangsa; Melaksanakan kebijakan yang dirumuskan pejabat pemerintah yang berwenang; Menaati ketentuan peraturan perundang-undangan; Melaksanakan tugas kedinasan dengan penuh pengabdian, kejujuran, kesadaran, dan tanggung jawab; Menunjukkan integritas dan keteladanan dalam sikap, perilaku, ucapan dan tindakan kepada setiap orang, baik di dalam maupun di luar kedinasan; Menyimpan rahasia jabatan dan hanya dapat mengemukakan rahasia jabatan sesuai dengan ketentuan perundang-undangan; dan Bersedia ditempatkan di seluruh wilayah NKRI.

Setelah memenuhi tugas dan kewajibannya, pegawai ASN memperoleh hak yang harus dipenuhi oleh instansi yang menaunginya. Hak-hak ASN tertuang dalam pasal 21 UU ASN bahwa berhak atas : gaji, tunjangan, dan fasilitas; cuti; jaminan pensiun dan jaminan hari tua; perlindungan; dan pengembangan kompetensi. Dalam penelitian ini diutamakan pada gaji dan tunjangan yang diterima ASN.

Gaji dan tunjangan ASN diatur dalam pasal 79 UU ASN, bahwa gaji yang diterima ASN haruslah sesuai dengan beban kerja, tanggung jawab dan resiko pekerjaan.Untuk besaran gaji yang diterima disesuaikan dengan dimana ASN tersebut bekerja.Jika ASN bekerja di pemerintahan pusat maka pemerintah pusatlah yang berhak menentukan besarannya, namun bila ASN bekerja di pemerintahan daerah maka besarannya sesuai dengan kemampuan daerah tersebut.Seluruh beban gaji ASN dibebankan pada APBN dan APBD.

Selain gaji, ASN juga menerima tunjangan dan fasilitas. Tunjangan yang dimaksud diatur dalam pasal 80 ayat (2) antara lain tunjangan kinerja dan tunjangan kemahalan. Tunjangan kinerja adalah tunjangan yang diberikan kepada ASN sesuai dengan pencapaian kinerja ASN, sedangkan tunjangan kemahalan adalah tunjangan 
yang diberikan sesuai dengan tingkat kemahalan berdasarkan indeks harga yang berlaku didaerah masin-masing. Sama seperti gaji, tunjangan ASN juga dibebankan pada APBN dan APBD sesuai dengan pemerintahan yang mempekerjakan ASN tersebut.

Menjelang hari raya Idul Fitri tahun 2018, presiden Joko Widodo menandatangani Peraturan Pemerintah nomor 19 tahun 2018 tentang pemberian Tunjangan hari raya bagi pns, tni, polri, pejabat negara, penerima pensiun, dan penerima tunjangan. PP ini dimaksudkan untuk memberikan tunjangan hari raya bagi ASN menjelang hari raya Idul Fitri.Tunjangan hari raya yang tertuang dalam pasal 3 ayat (1) PP 19 tahun 2018 sebesar penghasilan pada bulan mei, atau gaji pokok dan tunjangan kinerja.

Berlakunya PP 19 tahun 2018 membuat pemerintah daerah kalang kabut. Hal ini dikarenakan mereka tidak siap dalam memberikan tunjangan tersebut. Sebagian besar pemerintah daerah telah menempatkan anggarannya di berbagai pos pembelanjaan.Pemerintah daerah hanya menganggarkan pembelanjaan pegawai hanya untuk gaji ke-13 (gaji pokok+tunjangan) dan gaji ke-14 (hanya gaji pokok). Sehingga tidak ada dana tersisa dalam APBD di daerah baik tingkat provinsi dan kabupaten/kota. Dengan tidak adanya anggaran yang ada sebagian besar pemda tidak membayarkan THR sebagaimana yang diamanatkan oleh PP 19 tahun 2018.

\section{Pengaturan Pemberian Gaji dan Tunjangan}

Pegawai negeri sipil yang berkerja dibawah pemerintah pusat dan pemerintah daerah tunduk pada Undang- Undang nomor 5 Tahun 2014 tentang Aparatur Negeri Sipil, atau dalam penelitian ini disebut Undang-Undang ASN. Yang dimaksud ASN berdasarkan Undang-Undang ASN adalah profesi bagi pegawai negeri sipil dan pegawai pemerintahan dengan perjanjian kerja atau untuk selanjutnya disebut PPPK yang bekerja pada instansi pemerintah. Pegawai ASN tersebut diangkat oleh pejabat pembina kepegawaian dan diserahi tugas dalam suatu jabatan pemerintahan atau diberi tugas negara lainnya dan digaji berdasarkan peraturan perundang-undangan. Dalam menjalankan pekerjaannya, ASN wajib mematuhi asas, prinsip, nilai dasar, serta kode etik dan kode perilaku. 
Berdasarkan pasal 21 Undang-Undang ASN bahwa pegawai ASN berhak atas gaji, tunjangan, serta fasilitas. Skala penggajian serta tunjangan merupakan kebijakan yang ditetapkan oleh menteri yang terkait dalam pendayagunaan pegawai ASN. Dalam penggajian ASN, pemerintah wajib memberikan gaji yang layak dan adil kepada ASN agar terjamin kesejahteraan ASN, hal tersebut sesuai dengan pasal 79 Undang-Undang ASN. Gaji yang diberikan haruslah memperhatikan beban kerja, tanggung jawab, dan resiko pekerjaan. Pembebanan gaji ASN pusat, dibebankan pada APBN pusat, sedangkan ASN daerah dibebankan pada APBD daerah. Sama halnya dengan gaji, skala pemberian tunjangan sebagai salah satu hak yang dimiliki oleh ASN didasarkan pada ASN pusat maka dibebankan pada APBN pusat, serta ASN daerah dibebakan pada APBD daerah.

Kenaikan gaji diberikan dengan maksud bahwa untuk menjamin kesejahteraan ASN dan memberikan masa depan bagi ASN. Kenaikan gaji diberikan dengan syarat yang ditentukan dalam pasal 11 Peraturan Pemerintah gaji ASN yaitu :

a. Telah mencapai masa kerja golongan yang ditentukan untuk kenaikan gaji berkala;

b. Penilaian pelaksanaan pekerjaan dengan nilai rata-rata sekurang-kurangnya "cukup".

Syarat tersebut bersifat kumulatif, sehingga jika syarat pada huruf $b$ tidak terpenuhi maka kenaikan gaji berkala akan ditunda hingga syarat huruf b terpenuhi atau paling lama 1 tahun. Pelaksanaan kenaikan gaji didasarkan pada surat dari instansi atau kepala kantor satuan organisasi atas nama pejabat yang berwenang. Adapun lama waktu dari surat pemberitahuan dengan pelaksanaan kenaikan gaji adalah 2 bulan setelah surat diterbitkan.

Dengan perkembangannya dan demi menjamin kesejahteraan ASN, pemerintah memberikan tidak hanya 2 tunjangan yang telah tertuang dalam Undang-Undang ASN. Berdasarkan pasal 15 ayat (2) Peraturan Pemerintah Nomor 7 Tahun 1997, bahwa pegawai ASN tidak hanya mendapat tunjangan keluarga dan jabatan, tetapi mereka berhak atas tunjangan pangan serta tunjangan lain. Tunjangan lain yang diterima pegawai ASN merupakan upaya pemerintah 
dalam menjamin kesejahteraan ASN agar sesuai dengan tuntutan jaman. Untuk tunjangan dan ketentuan tentang pemberiannya diatur pada peraturan perundangundangan, tunjangan tersebut meliputi : Tunjangan Keluarga; Tunjangan Jabatan; Tunjangan Pangan; Tunjangan Umum; Tunjangan Khusus Provinsi Papua; serta Tunjangan Kinerja.

Untuk menunjang ASN dalam menyambut hari raya idul fitri, pemerintah mengeluarkan Peraturan Pemerintah Nomor 19 Tahun 2018 tentang Pemberian Tunjangan Hari Raya dalam Tahun Anggaran 2018 kepada Pegawai Negeri Sipil, Prajurit Tentara Nasional Indonesia, Anggota Kepolisian Negara Republik Indonesia, Pejabat Negara, Penerima Pensiunan, dan Penerima Tunjangan untuk selanjutnya Peraturan Pemerintah tunjangan Hari Raya. Tunjangan yang diberikan sebesar penghasilan pada bulan mei tahun 2018. Pada pasal 3 ayat (3)a dijelaskan bahwa besaran penghasilan yang dimaksud meliputi gaji pokok, tunjangan keluarga, tunjangan jabatan atau tunjangan umum, dan tunjangan kinerja. Besaran penghasilan yang dimaksud pada Peraturan Pemerintah tersebut, tidak dikenakan potongan iuran dan/atau potongan lainnya berdasarkan peraturan perundang-undangan.

Pada penjabaran sebelumnya, bahwa gaji dan tunjangan untuk ASN pusat dibebankan pada APBN. Pemberian gaji dan tunjangan tersebut didasarkan pada Manajemen ASN. Pada tahun 2018 pelaksanaan Manajemen ASN berada pada Menteri Dalam Negeri. Pada pasal 26 Undang-Undang ASN, Menteri berwenang dalam menetapkan kebijakan di bidang Pendayagunaan Pegawai ASN. Menteri tersebut menjalankan kebijakan umum Manajemen ASN meliputi klasifikasi ASN, standar kompetensi jabatan Pegawai ASN, kebutuhan ASN secara nasional, skala penggajian, tunjangan, dan sistem pensiun Pegawai ASN. Untuk menjalankan tugasnya di bidang pendayagunaan Pegawai ASN, Menteri Dalam Negeri bersinergi dengan Menteri Keuangan. Dalam hal skala pengajian dan pemberian tunjangan Pegawai ASN, Menteri Dalam Negeri wajib mendapat pertimbangan dari Menteri keuangan sebelum menetapkannya.

Dalam UU nomor 23 Tahun 2014 tentang Pemerintahan Daerah atau untuk seterusnya disebut UU Pemda, kewenangan kepala daerah tertuang dalam pasal 65 . 
Kepala Daerah mempunyai tugas salah satunya menyusun anggaran dan pengguna anggaran. Dalam hal penggunaan anggaran, Kepala Daerah dapat melimpahkan kewenangan baik seluruhnya maupun sebagaian kepada Perangkat Daerah yang ditunjuk untuk melaksanakan penggunaan anggaran. Perangkat Daerah merupakan badan pembantu Kepala Daerah dalam menyelenggarakan Urusan Pemerintahan yang menjadi kewenangan daerah. Setiap daerah dapat membentuk dinas-dinas terkait untuk membantu menjalankan urusan daerah sesuai kebutuhannya yang ditetapkan dengan Perda.

Pemberian gaji dan tunjangan yang dilakukan pemerintah tidak lepas dari hukum administrasi. Jika dilihat dari pendekatan keilmuan, hukum administrasi mengenal 3 pendekatan yaitu $;^{4}$

1. Pendekatan terhadap kekuasaan;

2. Pendekatan Hak Asasi;

3. Pendekatan Fungsional.

Dalam Hukum Administrasi yang berhak menetapkan suatu kebijakan atau aturan, serta penegakkannya adalah penguasa yang dalam konteks kehidupan bernegara di Indonesia adalah pemerintah Indonesia. ${ }^{5}$ Sebagai penguasa dalam kehidupan bernegara, segala tindakan pemerintah harus berdasar pada peraturan perundang-undangan yang berlaku atau dalam istilah lain keabsahan. Ruang lingkup keabsahan tindakan pemerintah adalah wewenang, prosedur, dan substansi. Tidak dipenuhinya 3 hal tersebut menyebabkan cacat hukum atas suatu tindakan pemerintah. Sehingga pendekatan ini merupakan kontrol dan pengawasan terhadap penggunaan kekuasaan oleh penguasa atau pemerintah.

Pendekatan hak asasi manusia berkaitan erat dengan fungsi hukum administrasi mengenai perlindungan hukum masyarakat. Sehingga pendekatan ini menitik beratkan pada pengawasan wewenang yang dimiliki oleh pemerintah. Selain dalam

${ }^{4}$ Tatiek Sri Djatmiati, 'Faute Personelle dan Faute De Service Dalam Tanggung Gugat Negara' (2004), 19 Yuridika.[353]

5 Philipus M Hadjon,dkk, Pengantar Hukum Administrasi Indonesia (Gadja Mada University Press 2015).[47]. 
bentuk perlindungan hukum masyarakat, pendekatan ini juga berfokus pada AsasAsas umum pemerintahan yang baik dan untuk seterusnya disebut AUPB. ${ }^{6}$

Pendekatan Fungsional didasarkan pada pelaksanaan kekuasaan pemerintahan yang dilaksanakan oleh seorang pejabat. ${ }^{7}$ Pejabat pemerintah dalam melaksanakan kekuasaan pemerintah dapat dilihat dari norma pemerintahan dan norma perilaku aparat. Sehingga pada pendekatan ini hukum administrasi tidak hanya bicara tentang norma pemerintahan tetapi norma perilaku aparat. Dalam Undang-Undang Nomor 37 Tahun 2008 tentang Ombudsman Republik Indonesia pasal 1 angka 3 dikenal adanya istilah maladministrasi bahwa perilaku atau perbuatan melawan hukum, melampaui wewenang, menggunakan wewenang untuk tujuan lain dari yang menjadi tujuan wewenang tersebut, termasuk kelalaian atau pengabaian kewajiban hukum dalam penyelenggaraan pelayanan publik yang dilakukan oleh Penyelenggara Negara dan pemerintahan yang menimbulkan kerugian materiil dan/atau immateriil bagi masyarakat dan orang perseorangan. Dalam praktiknya pengawasan terhadap perilaku pejabat pemerintahan dilaksanakan oleh instansi internal, namun diperlukan pula pengawasan dari eksternal guna menjamin tercapainya good governance dan hak-hak masyarakat. Di Indonesia pengawasan terhadap perilaku pejabat diserahkan kepada ORI (Ombudsman Republik Indonesia). Pembentukkan ORI mengadopsi dari sistem Ombudman pada pemerintahan Belanda, fungsi ombudsman berdasarkan aturan hukum Belanda untuk menguji tindakan pemerintah atas norma-norma kepantasan. ${ }^{8}$

Dari penjabaran 3 pendekatan tersebut, pendekatan keabsahan tindakan pemerintah yang sesuai jika dikaitkan dengan pemberian gaji dan tunjangan bagi ASN. Pemberian gaji dan tunjangan bagi ASN merupakan hak yang harus dipenuhi oleh organisasi pemerintahan. Kepala organisasi pemerintahan harus menjamin terpenuhinya gaji dan tunjangan ASN yang bekerja dibawah naungannya. Terutama

6 Jemmy Jefry Pietersz , 'Prinsip Good Governance Dalam penyalahgunaan Wewenang' (2017) Volume 3 Jurnal SASI.[175].

7 ibid.

8 Philipus M Hadjon,dkk. Loc. Cit.[295]. 
untuk pemberian tunjangan kinerja bagi ASN daerah. Sebab tunjangan yang diperikan kepada ASN daerah didasarkan pada APBD daerah setempat, sehingga besarannya sesuai dengan kemampuan daerah tersebut.

\section{Keabsahan Tindakan Pemerintahan dalam Penentuan Pemberian Gaji dan Tunjangan Hari Raya}

Beragama di Indonesia merupakan sesuatu yang esensial. Maka penjaminan warga negara Indonesia untuk menjalankan kegiatan beragamanya dengan bebas menjadi hal yang penting. Pada masa ini pemerintah mengakui adanya 6 agama yang ada di Indonesia antara lain : Islam, Hindu, Kristen, Katholik, Buddha, Kong hu cu. Semua agama tersebut mempunyai kegiatan ritual keagamaan masingmasing yang dijamin dan diakui pemerintah Indonesia. Terdapat banyak kegiatan hari raya, namun yang tertera dikalender nasional dan dinyatakan sebagai hari libur nasional di Indonesia antara lain :

1. Galungan;

2. Hari Raya Idul Adha;

3. Hari Raya Idul Fitri;

4. Jumat Agung;

5. Kenaikan Yesus Kristus;

6. Hari Raya Kuningan;

7. Maulid Nabi Muhammad;

8. Hari Raya Natal;

9. Nyepi;

10. Hari Raya Saraswati;

11. Tahun Baru Imlek; dan

12. Waisak;

Mulai tahun 2016 pemerintah Indonesia memberikan Tunjangan Hari Raya kepada selurun ASN. Tujuan pemberian THR tersebut dimaksudkan sebagai pengganti dari tidak dilaksanakannya kenaikan gaji secara berkala. Selain itu pemberian THR juga dimaksudkan untuk menunjang kegiatan para ASN dalam menyambut hari raya. Hari raya yang dimaksud adalah Hari Raya Idul Fitri, hal ini berdasarkan urgensi pengeluaran aturan menjelang libur Hari Raya Idul fitri.

Tindakan pemerintah dalam penentuan pemberian gaji dan tunjangan hari raya tidak lepas dari peraturan perundang-undangan yang berlaku di Indonesia. Keabsahan 
tindakan tersebut jika ditilik dari penjelasan sebelumnya bahwa unsur-unsur dari keabsahan suatu tindakan pemerintah yaitu: wewenang, prosedur, dan substansi.

Wewenang merupakan salah satu ruang lingkup keabsaahan, sehingga suatu tindakan pemerintah dianggap sah bila bertumpu pada kewenangan. Antara wewenang dan kewenangan memiliki perbedaan pengertian. ${ }^{9}$ Kewenangan pemerintah dalam menetapkan suatu keputusan didasarkan pada aturan hukum yang ada, sedangkan wewenang berkaitan dengan tindakan pemerintah. Kewenangan hanya dapat diperoleh melalui 2 cara yaitu atribusi atau dengan delegasi. ${ }^{10}$

Berdasarkan dasar hukum wewenang bersumber dari 3 hal yang telah disebutkan pada pasal 11 Undang-Undang Nomor 30 Tahun 2014 tentang Administrasi Pemerintahan untuk seterusnya disebut Undang-Undang APem. Pasal 1 angka 22 Undang-Undang APem bahwa “Atribusi adalah pemberian Kewenangan kepada Badan dan/atau Pejabat Pemerintahan oleh Undang- Undang Dasar Negara Republik Indonesia Tahun 1945 atau Undang-Undang.” Dengan pengertian diatas dapat diperoleh makna bahwa instansi pemerintah dan/atau pejabat pemerintah memperoleh wewenang didasarkan pada ketentuan pasal 12 Undang-Undang APem bahwa :

(1) Badan dan/atau Pejabat Pemerintahan memperoleh Wewenang melalui Atribusi apabila:

a. Diatur dalam Undang-Undang Dasar Negara Republik Indonesia Tahun 1945 dan/atau undang-undang;

b. Merupakan Wewenang baru atau sebelumnya tidak ada; dan

c. Atribusi diberikan kepada Badan dan/atau Pejabat Pemerintahan.

(2) Kewenangan Atribusi tidak dapat didelegasikan, kecuali diatur di dalam Undang-Undang Dasar Negara Republik Indonesia Tahun 1945 dan/atau undang-undang.

(3) Kewenangan Atribusi tidak dapat didelegasikan, kecuali diatur di dalam

9 Ateng Syafrudin, Menuju Penyelengaraan Pemerintahan Negara yang Bersih dan Bertanggung jawab (Bandung 2000)[22].

10 Philipus M Hadjon,dkk, Loc.Cit.[125]. 
Undang-Undang Dasar Negara Republik Indonesia Tahun 1945 dan/atau undang-undang.

Selain Atribusi, sumber wewenang juga diperoleh dari pelimpahan wewenang. Dalam pelimpahan wewenang dikenal dengan 2 jenis pelimpahan yaitu delegasi dan mandat. Pada pasal 1 angka 23 UU APem yang dimaksud delegasi merupakan prosedur pelimpahan wewenang dari suatu instansi pemerintahan dan/atau pejabat pemerintahan yang kedudukannya lebih tinggi kepada instansi atau pejabat pemerintahan dibawah, tanggung jawab dan tanggung gugat beralih kepada penerima pelimpahan wewenang. Sedangkan mandat merupakan pelimpahan wewenang dari instansi atau pejabat yang lebih tinggi kepada instansi/pejabat yang lebih rendah namun tanggung jawab dan tanggung gugat tetap berada pada pemberi mandat.

Penerapan PP Nomor 19 Tahun 2018 dalam pemberian tunjangan hari raya, tidak lepas dari pemerintah daerah. Sebagaimana yang dijabarkan sebelumnya, ASN terdiri dari ASN pusat dan ASN daerah. Sehingga pelaksaannya PP Nomor 19 Tahun 2018 pasti berkaitan dengan pelaksanaan pemerintah daerah.

Pada Undang-Undang Nomor 23 tahun 2014 tentang Pemerintah Daerah yang selanjutnya disebut UU Pemda, pasal 65 ayat (1) huruf d bahwa kewenangan kepala daerah kepala daerah berwenang untuk menyusun dan membentuk anggaran bersama dengan DPRD, serta melaksanakan program kegiatan sesuai dengan anggaran yang telah disepakati. Dalam menjalankan tugasnya menjalankan anggaran, kepala daerah dibantu oleh pejabat daerah. Pejabat daerah menjalankan kewenangan yang didelegasikan didasarkan pada Perda yang telah ditetapkan. Kepala daerah dan pejabat daerah menjalankan tugas dalam bidang keuangan berdasarkan APBD yang ditetapkan setiap tahunnya.

Pemerintah daerah wajib memenuhi gaji dan tunjangan hari raya bagi ASN daerah. Hal tersebut didasarkan pada ketentuan PP Nomor 19 Tahun 2018 pasal 9 huruf b bahwa, seluruh tunjangan hari raya dibebankan pada APBD. Ketentuan wajib pemenuhan tunjangan tersebut telah dijelaskan pada penjelasan sebelumnya bahwa UU ASN menjamin kesejahteraan Pegawai ASN. Pemenuhan tersebut tidak lepas dari perubahan APBD dalam kaitanya dengan pengelolaan keuangan negara 
dan pengelolaan keuangan daerah.

Penerapan PP Nomor 19 Tahun 2018 menjadi salah satu kebijakan strategis pemerintah pusat dalam mensejahterahkan ASN. PP Nomor 19 Tahun 2018 mempunyai kekuatan hukum tetap namun tidak terdapat sanksi bilamana terdapat daerah yang tidak dapat menjalankan ketentuan yang ada pada PP Nomor 19 Tahun 2018. Sanksi merupakan hal esesnsial didalam penegakan hukum. Sanksi dapat menimbulkan efek jera pada pelaku yang tidak menerapkan atau melaksanakan ketentuan hukum yang berlaku. Jika dikaitkan dengan pemerintah daerah yang tidak dapat mengimplementasikan ketentuan yang terdapat pada PP Nomor 19 Tahun 2018, maka perlu adanya ketentuan untuk menegakkan pelaksanaan pemberian THR bagi ASN. Secara umum terdapat 3 macam sanksi yaitu : sanksi administrasi, sansksi perdata, dan sanksi pidana. Pada praktiknya pemerintah dalam menegakkan suatu kebijakan mengedepankan penerapan sanksi administrasi dan menjadi sanksi pidana menjadi sanksi paling sebagai sanksi paling akhir atau ultimum remidium.

Sanksi administrasi yang khas dipergunakan antara lain: ${ }^{11}$

a. Bestuursdwang (paksaan pemerintah);

b. Penarikan kembali keputusan yang menguntungkan;

c. Pengenaan denda Administratif;

d. Pengenaan uang paksa oleh pemerintah.

Selain 4 sanksi diatas, pemerintah dapat menetapkan sanksi administrasi tersendiri yang disesuaikan dengan kondisi. Pembentukan sanksi tersebut dimaksudkan untuk terjamin dan tegaknya hukum administrasi.

Pemerintah daerah tunduk pada ketentuan UU Pemda, maka setiap tindakkannya berdasarkan pada UU Pemda. Salah satunya kewajiban dari kepala daerah berdasarkan pasal 67 huruf f bahwa kepala daerah wajib melaksanakan program strategis nasional. Prgram strategis nasional merupakan, program yang ditetapkan presiden bersifat strategis nasional dalam upaya peningkatan pertumbuhan dan pemerataan, serta meningkatkan kesejahteraan masyarakat. Hal ini sejalan dengan tujuan pemberian THR kepada ASN yang merupakan bagian dari masyarakat.

${ }^{11}$ ibid.[237]. 
Bagi pemerintah daerah yang tidak dapat menjalankan program strategis nasional akan diberikan sanksi admisntrasi. Hal tersebut didasarkan pada ketentuan pasal 68 ayat (1) UU Pemda, bahwa sanksi administrasi yang dijatuhkan kepada pemerintah daerah yang tidak menjalan kan program strategis nasional berupa teguran tertulis untuk kepala daerah. Dalam kaitanya dengan penegakan PP Nomor 19 Tahun 2018, Menteri bidang pendayagunaan ASN dapat memberikan teguran tertulis kepada kepala daerah yang tidak menjalankan peraturan tersebut.

Dalam pelaksanaan sanksi administrasi pasal 68 UU Pemda, jika pemerintah pusat melalui menteri sudah memberikan teguran tertulis sebanyak 2 kali berturutturut, kepala daerah dapat diberhentikan sementara selama 3 bulan. Selama waktu tersebut pemerintah pusat mewajibkan kepala daerah tersebut untuk mengikuti kegiatan pembinaan dalam bidang pemerintahan yang dilaksanakan kementerian terkait. Bilamana hingga waktu pemberhentian berakhir dan kepala daerah masih tetap tidak melaksanakan program strategis nasional, maka berdasarkan ketentuan pasal 68 ayat (3) UU Pemda, kepala daerah tersebut dapat diberhentikan dari jabatannya.

\section{Kesimpulan}

Berlakunya PP Nomor 19 Tahun 2018 tentang pemberian THR pada pegawai ASN merupakan salah satu bentuk penjaminan kesejahteraan yang dilakukan pemerintah. Pemberian THR tersebut ditujukan untuk seluruh ASN di Indonesia baik ASN pusat maupun ASN daerah. Pembebanan pemberian THR untuk ASN daerah dibebankan pada APBD daerah tersebut. Dengan penerapan pemberian THR bagi ASN didaerah, pemerintah daerah mengatur kembali anggarannya berdasarkan aturan-aturan yang berlaku mengenai pengelolaan keuangan daerah. Dalam implementasi PP Nomor 19 Tahun 2018 ditemukan adanya suatu permasalahan tidak pemerintah daerah gagal bayar yang menyebabkan hak ASN daerah dirugikan, maka pemerintah pusat wajib menerapkan sanksi. Sanksi yang dimaksud berupa teguran secara tertulis kepada pemerintah daerah yang tidak memenuhi ketentuan PP Nomor 19 Tahun 2018 sebagaimana mestinya. 


\section{Daftar Bacaan}

\section{Buku}

Philipus M. Hadjon, dkk, Pengantar Hukum Administrasi Indonesia, Cet. 12, (Gadja Mada University Press 2015).

Mahfud MD. Politik Hukum di Indonesia (Penerbit Lp3s 1998).

Siswanto Sunarno, Hukum Pemerintahan Daerah Di Indonesia (Sinar Grafika Offset 2008)

Roy R. Goode, Goode on Commercial Law (LexisNexis Butterworths 2016).

\section{Jurnal}

Abdul Rauf Alauddin Said, 'Pembagian Kewenangan Pemerintah PusatPemerintah Daerah Dalam Otonomi SeluasLuasnya Menurut UUD 1945’ (2015) 9 Fiat Justisia Jurnal Ilmu Hukum.

Fakthul Muin, 'Otonomi Daerah Dalam Persepektif Pembagian Urusan PemerintahPemerintah Daerah Dan Keuangan Daerah’(2014) 8 Fiat Justisia Jurnal Ilmu Hukum.

Jemmy Jefry Pietersz, 'Prinsip Good Governance Dalam Penyalahgunaan Wewenang' (2017) 3 Jurnal SASI.

Michael Barama, 'Pelaksanaan Pemerintahan Daerah Dan Penerapan Sanksi Administrasi Dalam Peraturan Daerah’ (2016) 22 Jurnal Hukum Unsrat.

Yusdianto, 'Hubungan Kewenangan Pusat dan Daerah Menurut UndangUndang Nomor 23 Tahun 2014 tentang Pemerintahan Daerah' (2015) 2 PADJADJARAN Jurnal Ilmu Hukum.

\section{Perundang-Undangan}

Undang-Undang Dasar Negara Republik Indonesia 1945.

Undang-Undang Republik Indonesia Nomor 23 Tahun 2014 tentang Pemerintahan Daerah (Lembaran Negara Republik Indonesia Tahun 2014 Nomor 244, Tambahan Lembaran Negara Republik Indonesia Nomor 5587).

Undang-Undang Republik Indonesia Nomor 2 Tahun 2015 Penetapan Peraturan Pemerintah Pengganti Undang-Undang Nomor 2 Tahun 2014 Tentang Perubahan Atas Undang-Undang Nomor 23 Tahun 2014 Tentang Pemerintahan Daerah Menjadi Undang-Undang (Lembaran Negara Republik Indonesia 
Tahun 2014 Nomor 246, Tambahan Lembaran Negara Republik Indonesia Nomor 5589).

Undang-Undang Republik Indonesia Nomor 5 Tahun 2014 Tentang Aparatur Sipil Negara (Lembaran Negara Republik Indonesia Tahun 2014 Nomor 6, Tambahan Lembaran Negara Republik Indonesia Nomor 5494).

Undang-Undang Republik Indonesia Nomor 9 Tahun 2015 Perubahan Kedua Atas Undang-Undang Nomor 23 Tahun 2014 Tentang Pemerintahan Daerah (Lembaran Negara Republik Indonesia Tahun 2015 Nomor 58, Tambahan Lembaran Negara Republik Indonesia Nomor 5679).

Undang-Undang Republik Indonesia Nomor 30 Tahun 2014 Tentang Administrasi Pemerintahan (Lembaran Negara Republik Indonesia Tahun 2014 Nomor 292, Tambahan Lembaran Negara Republik Indonesia Nomor 5601).

Undang-Undang Republik Indonesia Nomor 17 Tahun 2003 Tentang Keuangan Negara (Lembaran Negara Republik Indonesia Tahun 2003 Nomor 47, Tambahan Lembaran Negara Republik Indonesia Nomor 4286).

Peraturan Pemerintah Republik Indonesia Nomor 12 Tahun 2019 Tentang Pengelolaan Keuangan Daerah (Lembaran Negara Republik Indonesia Tahun 2019 Nomor 42, Tambahan Lembaran Negara Republik Indonesia Nomor 6322).

Peraturan Pemeritah Nomor 19 Tahun 2018 Tentang Pemberian Tunjangan Hari Raya Dalam Tahun Anggaran 2018 Kepada Pegawai Negeri Sipil, Prajurit Tentara Nasional Indonesia, Anggota Kepolisian Negara Republik Indonesia, Pejabat Negara, Penerima Pensiun, dan Penerima Tunjangan (Lembaran Negara Republik Indonesia Tahun 2018 Nomor 78, Tambahan Lembaran Negara Republik Indonesia Nomor 6028).

Peraturan Pemerintah Republik Indonesia Nomor 20 Tahun 2016 Tentang Pemberian Tunjangan Hari Raya Dalam Tahun Anggaran 2016 Kepada Pegawai Negeri Sipil, Prajurit Tentara Nasional Indonesia, Anggota Kepolisian Negara Republik Indonesia, Dan Pejabat Negara (Lembaran Negara Republik Indonesia Tahun 2016 Nomor 116, Tambahan Lembaran Negara Republik Indonesia Nomor 5889).

Peraturan Pemerintah Nomor 11 Tahun 2017 tentang Manajemen Pegawai Negeri Sipil (Lembaran Negara Republik Indonesia Tahun 2017 Nomor 63, Tambahan Lembaran Negara Republik Indonesia Nomor 6037).

Peraturan Pemeritah Nomor 30 Tahun 2015 Tentang Perubahan Ketujuh Belas Atas Peraturan Pemerintah Nomor 7 Tahun 1977 Tentang Peraturan Gaji Pegawai 
Negeri Sipil (Lembaran Negara Republik Indonesia Tahun 2015 Nomor 123, Tambahan LembaranNegara Republik Indonesia Nomor 3098).

Peraturan Pemeritah Nomor 07 Tahun 1997 Tentang Peraturan Gaji Pegawai Negeri Sipil (Lembaran Negara Republik Indonesia Tahun 1977 Nomor 11, Tambahan Lembaran Negara Republik Indonesia Nomor 3098). 
2122 Daniel Dwi: Pemenuhan Tunjangan Hari

--halaman ini sengaja dibiarkan kosong-- 